\title{
CURRENT STATE OF SOCIAL ENTREPRENEURSHIP IN TOURISM SECTOR OF THE REPUBLIC OF SERBIA
}

\author{
Ivana Marinović Matović ${ }^{1}$ (i) \\ Miloš Pavlović \\ Đorđe Dabetic ${ }^{3}$
}

DOI: https://doi.org/10.31410/tmt.2020.361

\begin{abstract}
The paper evaluates the current state and the rise of social entrepreneurship in the Republic of Serbia, with an emphasis on the tourism sector. The first section of the paper presents the social entrepreneurship concept, as well as a brief analysis of the relevant economic and legal environment for social entrepreneurship development in the Republic of Serbia. The paper identifies the key factors influencing social entrepreneurship development in the tourism sector of the Republic of Serbia. The main specific objective of this paper is an affirmation of social entrepreneurship in the tourism sector, while at the same time presenting the significant role of the legal and economic framework for the development of social entrepreneurship in the tourism sector of the Republic of Serbia.
\end{abstract}

Keywords: Social entrepreneurship, Tourism sector, SWOT analysis, Republic of Serbia.

\section{INTRODUCTION}

\begin{abstract}
$\mathrm{A}^{\mathrm{a}}$ though the idea of solidarity through business activities in the Republic of Serbia has been present for more than 150 years, on the traditional foundations of cooperatives (Pavlovic, 2015), the current state is unclear. The existing administrative, legal, investment and economic support for the social concept are not sufficiently effective. Social enterprises are the most active organizations in the EU and world social economy, where systematic actions are being done to support their growth and development.
\end{abstract}

Although it has roots in some economic forms from earlier socio-economic systems, under this name and with recognized significance for the national economy, social entrepreneurship emerged only after 2000. The rise of this concept in the Republic of Serbia after 2000 happened due to the increased social needs after the collapse of socialism, which led to new models of support for socially disadvantaged groups. The second reason is the importance of this concept for the social policy transformation in the European Union (EU). Like the EU, with its donations and standards for candidate countries, has the greatest influence on the social policy transformation in the Republic of Serbia, thus the social enterprise growth has been promoted as an important tool to help socially vulnerable citizens (European Commission, 2015).

Social entrepreneurship began to attract the attention of policy makers in the Republic of Serbia after 2008, when the economic situation deteriorated significantly, and when both political decision-makers and the professional public were forced to actively seek innovative solutions to economic problems, such as high unemployment. As a result, the Republic of Serbia has speed up the

\footnotetext{
$1 \quad$ Glenfield Training and Consulting, Belgrade, Serbia

2 Belgrade Business and Arts Academy of Applied Studies, Belgrade; Faculty of Economics, Kosovska Mitrovica, Serbia

3 Belgrade Business and Arts Academy of Applied Studies, Belgrade, Serbia
} 
development of social entrepreneurship and achieved this through the modification of legal regulations. At the same time, social entrepreneurship in the Republic of Serbia continued development through cooperation, knowledge, experience and information exchange, as well as lobbying.

This paper presents an overview of the social entrepreneurship development in the Republic of Serbia and the perspective of quality social enterprise in the tourism sector. Although social entrepreneurship, which we deal with in the paper, is a subject of frequent theoretical consideration, this study contributes to the literature with concrete recommendations for economic, social and political decision-makers dealing with tourism sector development. The paper is devoted to further study of social entrepreneurship in tourism, to accelerate its growth and development in our country. The development of the legal and economic framework for social entrepreneurship in the tourism sector would affect unemployment, as a burning problem, as well as social exclusion, which occurs at the same time as unemployment.

In order for the phenomenon of social entrepreneurship in the tourism sector to be analyzed as completely as possible, it is necessary to consider and take into account as many aspects and levels of social entrepreneurship development as possible, i.e. to analyze theoretical and practical interpretations from different angles, from the point of view of an individual as an entrepreneur, as well as from the perspective of the whole society.

\section{DEFINITION OF SOCIAL ENTERPRISE}

Although very popular in the last twenty years, the term social enterprise is not well defined, that is, there are doubts and differences between authors and institutions. The causes of poor definition are the novelty of term and concept, as well as different intellectual and cultural traditions of academics and institutions engaged in social entrepreneurship.

In literature and practice, the term "social entrepreneurship" appeared in the late 1980s in Italy, and this term was used for organization whose existence was not based on economic profit, but social goals. Social enterprises are performing economic activities, but have a strong orientation toward social goals and community interests.

Social enterprises may be prohibited by law from distributing profit or may eliminate profit as a business objective (Cvejić, Babović, Vuković, 2008). Social enterprises have multiple benefits for society: provide goods or services for vulnerable categories of the population; contribute to the development of underdeveloped regions; create new jobs, especially for hard-to-employ categories of the population. Some of the most widely accepted definitions of social enterprise are summarized in Table 1:

Table 1. Definitions of social enterprise

\begin{tabular}{|l|l|}
\hline Source & Definition \\
\hline $\begin{array}{l}\text { European Commission. (2011). The Communication on the } \\
\text { https://eur-lex.europa.eu/legal-content/EN/ }\end{array}$ & $\begin{array}{l}\text { Social enterprise is an operator in the social economy whose } \\
\text { main objective is to have a social impact rather than make } \\
\text { TXT/?uri=CELEX:52011DC0682 } \\
\text { a profit for their owners or shareholders. It operates by pro- } \\
\text { viding goods and services for the market in an entrepreneur- } \\
\text { ial and innovative fashion and uses its profits primarily to } \\
\text { achieve social objectives. It is managed openly and respon- } \\
\text { sibly and involves employees, consumers and stakeholders } \\
\text { affected by its commercial activities. }\end{array}$ \\
\hline
\end{tabular}




\begin{tabular}{|c|c|}
\hline $\begin{array}{l}\text { Defourny, J., Nyssens, M. (2008). Social Enterprise } \\
\text { in Europe: Recent Trends and Developments, Social } \\
\text { Enterprise Journal, 4(3): } 206 .\end{array}$ & $\begin{array}{l}\text { Social enterprises are not-for-profit private organizations } \\
\text { providing goods or services directly related to their explicit } \\
\text { aim to benefit the community. They rely on a collective dy- } \\
\text { namic involving various types of stakeholders in their gov- } \\
\text { erning bodies, they place a high value on their autonomy and } \\
\text { they bear economic risks linked to their activity. }\end{array}$ \\
\hline $\begin{array}{l}\text { Social Enterprise. (2019, April 15). } \\
\text { https://www.investopedia.com/terms/s/social-enterprise.asp }\end{array}$ & $\begin{array}{l}\text { A social enterprise is a commercial organization that has } \\
\text { specific social objectives that serve its primary purpose. So- } \\
\text { cial enterprises seek to maximize profits while maximizing } \\
\text { benefits to society and the environment. Their profits are } \\
\text { principally used to fund social programs. }\end{array}$ \\
\hline OECD (1999), Social Enterprises, OECD, Paris. & $\begin{array}{l}\text { Social enterprise deals with any private activity conducted in } \\
\text { the public interest, organized with an entrepreneurial strate- } \\
\text { gy, but whose main purpose is not the maximization of profit } \\
\text { but the attainment of certain economic and social goals, and } \\
\text { which has the capacity for bringing innovative solutions to } \\
\text { the problems of social exclusion and unemployment. }\end{array}$ \\
\hline $\begin{array}{l}\text { Social enterprise. (2019). } \\
\text { https://en.wikipedia.org/wiki/Social_enterprise }\end{array}$ & $\begin{array}{l}\text { Social enterprise is an organization that applies commercial } \\
\text { strategies to maximize improvements in financial, social and } \\
\text { environmental well-being - this may include maximizing } \\
\text { social impact alongside profits for external shareholders. }\end{array}$ \\
\hline $\begin{array}{l}\text { What Is A Social Enterprise? A Simple Definition \& } 3 \\
\text { Examples (2019). The Good Trade. } \\
\text { https://www.thegoodtrade.com/features/what-is-a-social- } \\
\text { enterprise }\end{array}$ & $\begin{array}{l}\text { Social enterprise is a cause-driven business whose primary } \\
\text { reason for being is to improve social objectives and serve the } \\
\text { common good. }\end{array}$ \\
\hline $\begin{array}{l}\text { Austin, J.E., SEKN Team. (2004). Social Partnering in } \\
\text { Latin America, Cambridge Mass: Harvard University. }\end{array}$ & $\begin{array}{l}\text { Any kind of organization engaged in activities of significant } \\
\text { social value, or the production of goods and services with an } \\
\text { embedded social purpose, regardless of legal form. }\end{array}$ \\
\hline
\end{tabular}

Source: Authors

The social enterprise is denoted by the following categories: economic and entrepreneurial dimension, social dimension, and participatory governance of social enterprises (EMES, 2001). There is no universally accepted definition of social enterprise, however, the central idea is obvious - to supplement state activity in the social sphere with private sector activity, which should bring entrepreneurial spirit and efficiency.

\section{BRIEF HISTORY OF SOCIAL ENTREPRENEURSHIP IN EUROPE AND THE REPUBLIC OF SERBIA}

Social entrepreneurship has emerged in the 18th and 19th centuries. The industrial revolution in Europe led to the impoverishment of working class, and it has encouraged new initiatives for poverty reduction. New initiatives originally appeared in Italy and France, where the process of industrial development itself was slower, and where there was a tradition of cooperatives (Anheier, 2005).

A turning point in the development of social entrepreneurship in Europe happened during the 1980s (Defourny \& Nyssens, 2008) when many European countries faced high structural unemployment, which they could not cope with traditional social policy mechanisms. Public policy creators have been given the task of creating adequate public policies, which would enable certain population groups to enter the labor market, such as individuals who have been out of work for a long time, or individuals who are insufficiently qualified, etc. 
In response to the new economic situation in European countries, various types of social enterprises have evolved. Civic associations and foundations, that have traditionally been socially oriented, got involved in a profitable business with stronger entrepreneurial initiatives (Cvejić et al., 2008). Cooperatives, instead of their own profitable business goals, focused on meeting the social needs in the country (Cvejić et al., 2008).

In Europe, social entrepreneurship had its beginnings in Italy, where the first social enterprises were established. First social enterprises were called "Cooperative sociale" to include vulnerable groups in the labor market (Defourny \& Nyssens, 2008). They were regulated by the "Italian Law on Social Cooperatives of 1991" (Fici, 2015). Between 1991 and 2003, there were 6,5007,000 Cooperatives sociale established in Italy, employing some 200,000 workers and contributing to the well-being of 1.5 million people (Borzaga et al., 2008). Social enterprises were soon established in other European countries. "Cooperatives of Social Solidarity" (Cooperativas de solidariedade social) have been established in Portugal; "Cooperative societies of collective interests" (Societe cooperative d'interet collectif SCIC) were introduced in France; "Community interest company" were founded in England, providing services such as local transport, social housing, childcare, etc. (Velev, 2011).

Today, just traditional social economy organizations (cooperatives, associations, foundations) make an impressive number of two million. They make a significant contribution to all European business (10 to 12\%), and are employing 14.5 million people. Besides, cooperatives have 140 million members, making every fifth European member of the cooperative (Cooperatives Europe, 2016).

The social entrepreneurship idea in the Republic of Serbia has been present for more than 150 years on traditional foundations of cooperatives (Pavlovic, 2015). The first cooperative was founded in 1868 in Titel, Vojvodina (Parun Kolin \& Petrušić, 2007). Until World War II, cooperatives in the Republic of Serbia were one of the most developed economic sectors, as evidenced by the fact that Serbian cooperatives were one of the founders of the International Co-operative Alliance (ICA) in London in 1895 (Zakic \& Nikolic, 2018).

Two specifics in cooperatives development in the Republic of Serbia have diminished the significance of this historical heritage. The cooperatives were originally developed in villages, as producer cooperatives or credit unions (agricultural cooperatives), which served to protect peasants and small landowners, threatened by agriculture modernization in the early 20th century. The cooperative spirit has been negligibly expanded to other spheres of economy, since the first Cooperative Law, which regulated other forms of cooperatives, was introduced in 1937 (Stojanovic \& Gnjatovic, 2015). Then, during the period of socialist regulation (1945-1990), as well as during the period of post-socialist (unsuccessful) transition (1990-2000), social enterprises in the form of cooperatives were strongly influenced by the state, which imposed restrictions on them, and led to a reduction in their activities (Cvejić, 2018).

In the late 1980s, the Law on Cooperatives (1989) was adopted, and an attempt was made to reaffirm the cooperative movement. One of the basic problems faced by cooperatives was the unresolved property ownership, since a significant part of the cooperative property was socially owned (Parun Kolin \& Petrušić, 2007). In the late 1990s, a new Law on Cooperatives (1996) was adopted, as well as a new General Rules of Cooperative Union of Yugoslavia (1998), but their implementation did not lead to a significant improvement, nor towards solving the problem 
of cooperative property ownership. Cooperatives have undergone significant legal and organizational changes since 2000, and together with non-profit organizations have created a legal and organizational basis for social enterprise development in the Republic of Serbia.

Contemporary social entrepreneurship has emerged in the Republic of Serbia through the process of approaching the European Union, with some specifics. The Republic of Serbia has long been characterized by a significant economic development lag, accompanied by economic problems. As a result, the number of citizens not included in standard market mechanisms is higher than in most European countries. These problems threaten the entire economy and, therefore, the strengthening of social enterprises may to some extent relieve the market economy of high social expectations.

An aggravating factor for the social enterprises' development is the poor entrepreneurial spirit in the Republic of Serbia. The country first went through 45 years of socialism, during which private entrepreneurship was suppressed. Then, the 1990s were marked with suspicious privatization and corruption that compromised the entrepreneurship idea and practice. An additional problem facing the social enterprises in the Republic of Serbia is the lack of legal and economic framework, as well as the lack of adequate financial incentives both for creating its activities and for maintaining current business. The existence of a stimulating environment in form of the legal and economic ecosystem would facilitate the establishment and operations of social enterprises. A stimulating environment would successfully shape the social entrepreneurship sector in the Republic of Serbia.

\section{TYPES OF SOCIAL ENTERPRISES IN THE REPUBLIC OF SERBIA}

Social enterprises are categorized within seven legal and business forms in the Republic of Serbia, which correspond to the concept of social entrepreneurship: cooperatives, enterprises for employment and vocational rehabilitation of persons with disabilities, civic associations and foundations (non-profit organizations), limited liability companies and joint-stock companies (usually spin-offs of non-profit organizations, business incubators or development agencies) (Cvejić et al., 2008; Vukmirović et al., 2014).

Cooperatives. Cooperatives in the Republic of Serbia are more oriented towards promoting the interests of their members than the public interest in the local community. Membership in some cooperatives consists of specific vulnerable groups (small agriculturists, poor craftsmen, unskilled workers), so they are specifically supporting the interests of these groups, or provide basic social protection services (health care, housing, poverty eradication) and therefore considered social enterprises.

Enterprises for employment and professional rehabilitation of persons with disabilities. The most developed type of social enterprise in the Republic of Serbia, which is defined under the Law on Professional Rehabilitation and Employment of Persons with Disabilities (2009) as a form of employment and professional development of persons with difficult employment possibilities. Their activities are regulated by the Companies Law (2011), but they receive significant state subventions and have priority at public tenders.

Civic Associations and Foundations. They emerge as an important and competitive actor in social care services (SeConS, 2013). Associations and foundations are mostly founded to 
explicitly pursue social goals and accomplish their social mission. Another characteristic that highlights the strong social dimension of associations or foundations is their orientation to vulnerable categories of the population as defined by The Social Welfare Act (2011).

Limited Liability Companies and Joint Stock Companies. This legal and business form of social enterprise is the rarest in the Republic of Serbia. They are mostly set up by associations to financially support their social goals through the commercial business. In this case, these limited liability companies and joint-stock companies operate as spin-offs or business incubators. If established by local or national governments, they usually operate as development agencies. Social enterprises that are registered as limited liability companies and joint-stock companies also generate income from other sources. They receive donations and various types of local government support.

\section{LEGAL AND ECONOMIC ENVIRONMENT FOR SOCIAL ENTREPRE- NEURSHIP IN THE REPUBLIC OF SERBIA}

The functioning of most social enterprises in Europe is governed by the Law on Cooperatives, the Act on Associations, or the Law on Social Enterprises (Velev et al., 2011). Additional legislation forms have been enforced in many countries to encourage innovative, modern forms of social entrepreneurship.

The legal framework governing social entrepreneurship in the Republic of Serbia is not adequately shaped, despite its importance and positive effects being recognized in the civic sector and professional public. However, several laws, bylaws, and regulations are governing the fields of social enterprise activity, its constitution, and operation, as well as taxation. These are: The Social Welfare Act (2011); Law on Professional Rehabilitation and Employment of Persons with Disabilities (2009); Act on Associations (2009); Law on Endowments and Foundations (2010); Companies Law (2011); Law on Cooperatives (2015); Law on Volunteering (2010); Public Procurement Law (2012); Labor Law (2005); Legal Entity Profit Tax Law (2001) and Value Added Tax Law (2004).

The goal that should be pursued is the adoption of systemic law in this area, as the solutions in EU countries, respecting the transitional specificities in the Republic of Serbia. Adoption of comprehensive law should consider the current situation in social entrepreneurship, the other countries' experiences, as well as practice as a source for positive legal norms.

Considering the legal framework for social entrepreneurship development in the Republic of Serbia, it can be concluded that different laws shape this area of action. The most important laws that regulate this concept are the Companies Law, the Legal Entity Profit Tax Law, the Value Added Tax Law and the Act on Associations. Social entrepreneurship receives minimal subsidized funds, while tax liabilities are almost identical to those applicable to for-profit organizations.

Other sources of funding are available to social enterprises in the Republic of Serbia, and that are, first of all, funds for the establishment and performance of social enterprises. There are funds for financing vulnerable and marginalized groups, as well as the funds for financing the social enterprises' growth and development. Within each of these three groups of sources, there are funds financed from the Republic of Serbia budget, Vojvodina budget, or local budget; then funds of non-governmental organizations dealing with the area of interest; as well as foreign funds (see more in the European Movement in Serbia, 2011). 
In addition to strengthening existing structures for the use of EU funds for social inclusion and poverty reduction, it is necessary to establish a Social Inclusion Fund that would affect the more efficient use of available EU funds for social inclusion (Third National Report on Social Inclusion and Poverty Reduction in the Republic of Serbia, 2018). The establishment of such a fund is in line with the need to set up a national fund equivalent to the European Social Fund.

\section{SWOT ANALYSIS OF SOCIAL ENTREPRENEURSHIP IN TOURISM SECTOR}

Social enterprises in the tourism sector in the Republic of Serbia could play a significant role in social development, but they are conditioned with the certain general framework. The most important driving factors for their development and growth are positive historical heritage, entrepreneurial approach to social problems, strengthening public awareness, EU influence, network development as support platforms, institutional sensitivity (Aleksić Mirić \& Lebedinski, 2015; Borzaga et al., 2008).

Positive historical heritage - Serbian culture values social motives. The importance of positive historical heritage is huge for the future development of social enterprises in the tourism sector. Entrepreneurial approach to social problems - Reduced reliance on the state has led to independent organizing of citizens. Strengthening public awareness - The public is becoming increasingly aware of the need for active involvement in social issues.

EU impact - EU impact has a positive effect on the social entrepreneurship development in the tourism sector, reflecting through donation programs, and learning from international organizations (Borzaga et al., 2008). Network development as support platforms - It is an important tool for supporting social enterprises because it enables pooling of resources, better lobbying and advocacy (Borzaga et al., 2008). Institutional sensitivity - Increasing initiatives of competent institutions, aimed at the needs of disadvantaged categories, such as active labor market measures, employment laws, insurance, ban on discrimination against disadvantaged categories (Borzaga et al., 2008).

Social entrepreneurship in the tourism sector faces many challenges that restrain its emergence, growth and development. As the most important stand out (Vukmirović et al., 2014; Aleksić Mirić \& Lebedinski, 2015; Borzaga et al., 2008):

Suspicion towards social concept - In the Republic of Serbia there is a certain suspicion towards enterprises that have a "social" status in their name. Uncompleted transformation of legal framework - Legal regulation in this area must be approached carefully, analyzing all relevant effects.

Limited access to financial resources - Commercial banks have a very conservative attitude towards entrepreneurs, also towards enterprises with a social mission. Weak economy - Although the Republic of Serbia has implemented significant reforms in many fields, one of the biggest obstacles to social entrepreneurship in the tourism sector is low economic development and a large shadow economy.

Poor employment potential - Existence of significant rigidity in the labor market, and relatively limited mobility of the working population in the Republic of Serbia. Excessive pressure from numerous disadvantaged groups - Social welfare expenditures is a large part of the state budget. Social enterprises supplement state obligations that haven't been systematically resolved and for 
which there is insufficient capacity. Development instability - Social enterprises in the tourism sector need support throughout the entire cycle of their development, not only financially, but also in the process of developing business skills.

Lack of entrepreneurial culture - Serbian national culture, by its basic characteristics (Hofstede, 2001), is not entrepreneurial and shows a very low-risk appetite. Low awareness of social enterprises' importance - Low awareness is present among all stakeholders and potential social beneficiaries. The awareness of the importance of social entrepreneurship in the tourism sector should be strengthened, as an important future development factor in the Serbian economy.

Unrealistic expectations from the state - The modest development of social enterprises in the tourism sector so far can also be explained by a fundamental misunderstanding of state institutions. Poor financial discipline - Poor economic environment and legal uncertainty lead to a low degree of financial discipline. Corruption - High corruption level in the Republic of Serbia affects all segments of society, as well as social entrepreneurship in the tourism sector.

Based on the aforementioned advantages and disadvantages, that have a positive or negative impact on social entrepreneurship in the tourism sector, opportunities for its development could be identified, as well as threats. Following is a summary of the author's views on the advantages and disadvantages of social entrepreneurship in the tourism sector, through a SWOT (strengths, weaknesses, opportunities, and threats) analysis.

SWOT-analysis helps in identifying the main strengths (advantages) and weaknesses (disadvantages), as well as opportunities (possibilities) and threats (constraints) for developing social entrepreneurship in the tourism sector in the Republic of Serbia. Table 2 shows the main findings of SWOT analysis of social entrepreneurship in the tourism sector in the Republic of Serbia.

Presented SWOT analysis can be used to establish opportunities and threats of social entrepreneurship in the tourism sector in the Republic of Serbia, its competitiveness, as well as to develop an economic and legal framework that would facilitate the social entrepreneurship development. SWOT analysis assessed the internal and external factors that represent the strengths, weaknesses, opportunities and threats, that is, the present and future potential of social entrepreneurship in the tourism sector in our country.

Based on the presented SWOT analysis, all stakeholders in the social entrepreneurship context should be aware that further development can be accelerated if they focus on their strengths, that is, on strong entrepreneurial orientation, flexibility, social business goals, competitiveness, sensitivity to disadvantaged groups, diversity of goals and activities, organizational dynamism, motivation, economic integration of persons with disabilities, adaptation to working abilities of persons with disabilities and rich cooperative tradition.

In the process of focusing on strengths, social entrepreneurship in the tourism sector should minimize its weaknesses, above all conflict of interest in the case of several founders, low entrepreneurial affinity, insufficient experience in management positions, inadequate qualifications, lack of financial resources, absence of long-term planning, operating losses, unadjusted physical conditions for persons with disabilities, inadequate legal framework, as they are the biggest obstacles to growth. 
Table 2. SWOT analysis of social entrepreneurship in the tourism sector

\begin{tabular}{|c|c|}
\hline$S$ & W \\
\hline $\begin{array}{l}\text { - } \begin{array}{l}\text { Strong entrepreneurial orientation of social } \\
\text { - }\end{array} \text { High degree of adaptability to market requirements } \\
\text { - Social business goals } \\
\text { - Competitiveness } \\
\text { - Need for helping to vulnerable groups of } \\
\text { population } \\
\text { - Large degree of diversification, in the area of set } \\
\text { goals, in accordance with the needs of certain } \\
\text { groups of the population } \\
\text { - Flexibility and innovation of social enterprises } \\
\text { - High level of expertise, motivation and } \\
\text { commitment of employees } \\
\text { Employment of categories of population with } \\
\text { special needs and disabilities } \\
\text { Rich cooperative tradition }\end{array}$ & $\begin{array}{l}\text { - Conflict of interest in the case of the existence of } \\
\text { several founders } \\
\text { - Low entrepreneurial affinity } \\
\text { Insufficient experience in management positions, } \\
\text { inadequate qualifications } \\
\text { - Lack of financial resources to finance all operating } \\
\text { phases of a social enterprise } \\
\text { - Lack of planning in longer time frames } \\
\text { Certain unplanned activities can lead to business } \\
\text { losses } \\
\text { insufficiently adapted to people with special needs } \\
\text { and disabilities } \\
\text { Inadequate law regulative, not adapted to the needs } \\
\text { of social entrepreneurship }\end{array}$ \\
\hline $\mathbf{O}$ & 1 \\
\hline 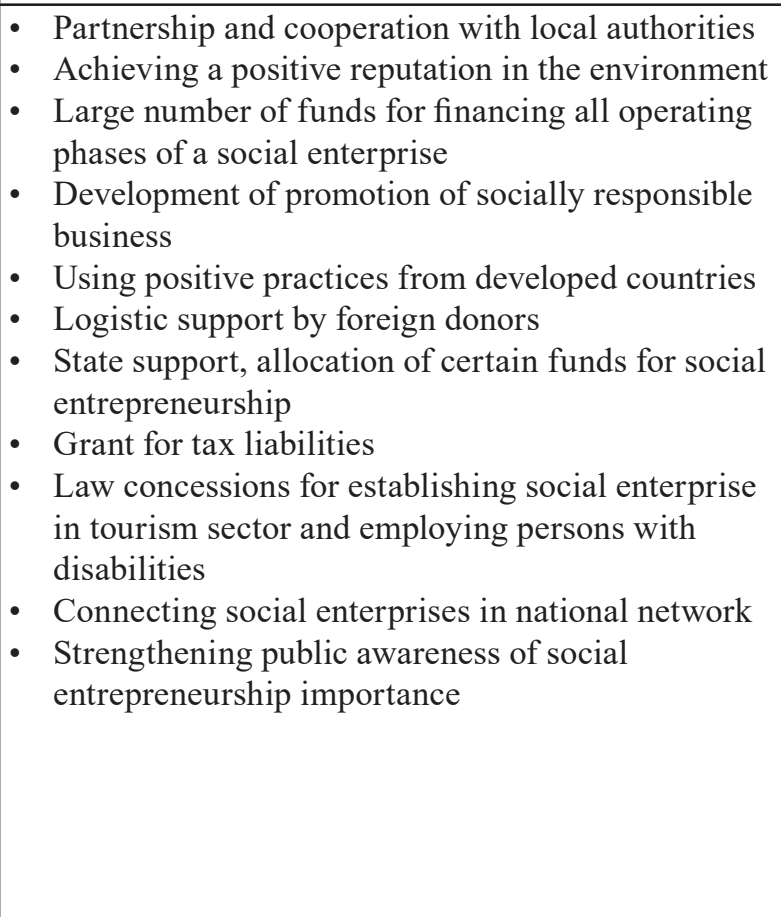 & $\begin{array}{l}\text { - Not recognizing the value of work, benefits and } \\
\text { initiatives from social entrepreneurship } \\
\text { - High corruption level reflected through public } \\
\text { - Locurement } \\
\text { - Unstable market } \\
\text { - Unfavorable legal framework } \\
\text { - Administrative barriers } \\
\text { - Misuse of social entrepreneurship concept in order } \\
\text { - to use favorable financial resources } \\
\text { - Inconsistent interpretation of tax regulations } \\
\text { Insufficiently active state role in creating favorable } \\
\text { conditions for social entrepreneurship } \\
\text { Negative prejudices towards social } \\
\text { entrepreneurship, originated from the period of } \\
\text { - Incialism } \\
\text { - Uninformate cooperation with local authorities } \\
\text { social enterprise establishment } \\
\text { - Uninformed entrepreneurs on employing persons } \\
\text { with disabilities } \\
\text { Emigration of high educated population }\end{array}$ \\
\hline
\end{tabular}

Source: Authors, based on EMES (2001) and Cvejić et al. (2008).

Focusing on strengths and minimizing weaknesses will enable social entrepreneurship to take advantage of available development opportunities in the tourism sector: partnership and cooperation with local authorities, positive image, use of various financial sources, promotion of socially responsible business, using positive practices from developed countries, logistic support by foreign donors, state support, allocation of certain funds for social entrepreneurship, tax concessions, concessions in establishing social enterprise and employing persons with disabilities, connecting in the national network and strengthening public awareness of social entrepreneurship importance.

Opportunities for the growth of social entrepreneurship in the tourism sector may be partially reduced due to the presence of certain environmental threats, i.e. external conditions that are unfavorable (possible problems such as: not recognizing the value of social entrepreneurship, 
high corruption level, low financial discipline, unstable market, unfavorable legal framework, administrative barriers, misuse of social entrepreneurship concept in order to use favorable financial resources, inconsistent interpretation of tax regulations, insufficiently active state role in creating favorable conditions for social entrepreneurship, negative attitude, inadequate cooperation with local authorities, misinformation on the social enterprise establishment, misinformation on employing persons with disabilities, emigration of the high educated population).

\section{CONCLUSION}

Social enterprise operates with the idea of fulfilling a social mission through earning revenue from selling products or services. For this reason, in addition to the importance for Serbian economic development, social enterprises have an extremely important role in solving social issues and have a great impact on the whole society. There is a real need for social entrepreneurship in the Republic of Serbia, and there is a tradition of joint market appearance with a social mission.

Social entrepreneurship in the function of tourism sector development should contribute to the optimal engagement of available resources, activation of intangible heritage in the function of entrepreneurial activities, job creation, economic and social empowerment of local communities and ensuring a self-sustainable long-term business. By careful observation of the development of social entrepreneurship in the tourism sector on the territory of the Republic of Serbia, it can be concluded that the principle of social entrepreneurship development is present primarily through encouraging the development of rural tourism. Rural tourism means a set of all tourist activities that are realized in rural areas and as such provides a wide range of social entrepreneurial activities in the field of tourism and complementary areas that can be realized in rural areas of the Republic of Serbia, in accordance with the principles of sustainable development. From this point of view, the development of social entrepreneurship is a tool for achieving environmental, economic and socio-cultural well-being in rural areas in order to raise the quality of life of the local population from both material and intangible aspects.

The two most common problems faced by social enterprises in the tourism sector in the Republic of Serbia are the non-continuous inflow of financial resources and an inadequate legal framework adapted to the needs of social enterprise. On the other hand, a major problem is the lack of entrepreneurial affinity and adequate knowledge and skills, important for the management quality and sustainability of social enterprises in the tourism sector.

The legal framework, governing social entrepreneurship in the Republic of Serbia, does not adequately recognize the "social entrepreneurship" concept. There is no legal regulation that comprehensively governs this matter, but several laws and strategies regulating social enterprises. The goal to be pursued is the adoption of systemic law in this area, as the solutions in EU countries, while respecting the specificities of the Republic of Serbia.

Financial support for enterprises with social goals is minimal, with tax liabilities almost the same as for-profit enterprises. Social enterprises are focused on domestic and foreign sources of financing, funds for financing their establishment and operation, funds for financing different needs of vulnerable groups, and funds that represent sources of financing more favorable than on Serbian financial market. It is necessary to set up a Social Inclusion Fund, to support social inclusion programs for more vulnerable groups, and to influence the more efficient use of available EU funds. 
SWOT analysis showed that social enterprises in the tourism sector have development opportunities in the Republic of Serbia. First, it is necessary to overcome the weaknesses of social enterprises, as well as to overcome resistance to this idea, and to strengthen public awareness of their importance. In this process, state support should be moderate and reasonable, in line with the real effects that social enterprises have on solving social and similar problems in the tourism sector, without discrimination.

The development of a legal framework to support social entrepreneurship in the tourism sector in the Republic of Serbia should be approached gradually but dynamically. A comprehensive overview of the current state of social entrepreneurship is needed, and good coordination between ministries and the social enterprise sector should be established. It is especially important to develop an adequate economic framework, more precisely financing options, through the development of financial institutions and instruments that support the social enterprises in the tourism sector in all stages of development.

Finally, government support is needed for creating a favorable climate for social enterprises in the tourism sector, such as reducing corruption, increasing financial discipline, increasing market stability, reducing administrative barriers. Social entrepreneurship in the tourism sector should be recognized and supported by measures that will enable its independent development.

State role should be much more active in creating favorable conditions for social entrepreneurship. Support programs for management skills development, for managers of social enterprises (planning, controlling, marketing, accounting, IT and other skills), are certainly important in this domain, and adoption of knowledge and experience from other countries, with more developed social entrepreneurship in the tourism sector. Direct financial government support grants and various funds for social entrepreneurship in the tourism sector are also important, as well as tax concessions and concessions stipulated by the law in establishing social enterprise and employing persons with disabilities. The state should also have an active role in strengthening public awareness of social entrepreneurship's importance in the tourism sector.

\section{REFERENCES}

Act on Associations. (2009). Official Gazette of RS, Nos. 51/2009, 99/2011, 44/2018.

Aleksić Mirić, A., Lebedinski, L. (2015). Social entrepreneurship in Serbia: an overview and perspectives. In: Economic policy of Serbia in 2015 (pp. 219-228). Belgrade: Faculty of Economics. http://ebooks.ien.bg.ac.rs/1152/1/Ekonomska\%20politika\%20Srbije\%20u\%20 20151.pdf

Anheier, H.K. (2005). Nonprofit Organizations - Theory, Management, Policy. London: Routledge Publishing.

Austin, J.E., SEKN Team. (2004). Social Partnering in Latin America. Cambridge Mass: Harvard University.

Borzaga, C., Galera, G., Nogales, R. (2008). Social Enterprise: A new model for poverty reduction and employment generation. UNDP Regional Bureau for Europe and the Commonwealth of Independent States. https://emes.net/content/uploads/publications/11.08_EMES_ UNDP_publication.pdf

Companies Law. (2011). Official Gazette of RS, Nos. 36/2011, 99/2011, 83/2014, 5/2015, 44/2018, 95/2018. 
Cooperatives Europe. The Power of cooperation: Cooperatives Europe key figures 2015. (2016). https://coopseurope.coop/sites/default/files/The $\% 20$ power $\% 20$ of $\% 20$ Cooperation $\% 20$ -\%20Cooperatives\%20Europe\%20key\%20statistics\%202015.pdf

Cvejić, S. (2018). Social enterprises in Serbia. In A. Kostić (Ed.), Economy, employment and work in Serbia in the 21st century, (pp.343-368). Belgrade: SANU. https://solidarnaekonomija.rs/wp-content/uploads/2018/11/Socijalna-preduzeca-u-Srbiji-2018_Cvejic.pdf

Cvejić, S., Babović, M., Vuković, O. (2008). Mapping of social enterprises in Serbia. Belgrade: UNDP. https://www.secons.net/files/publications/23-\%20Mapiranje\%20socijalnih\%20 preduze $\% \mathrm{C} 4 \% 87 \mathrm{a} \% 20 \mathrm{u} \% 20$ Srbiji.pdf

Defourny, J., Nyssens, M. (2008). Social Enterprise in Europe: Recent Trends and Developments, SocialEnterprise Journal, 4(3), 202-228. https://pdfs.semanticscholar.org/06f6/0148384e63672d6317341d8d5cf37f4da348.pdf

EMES. (2001). Social enterprise. https://emes.net/focus-areas/

European Commission. (2011). The Communication on the Social Business Initiative (SBI). https://eur-lex.europa.eu/legal-content/EN/TXT/?uri=CELEX:52011DC0682

European Commission. (2015). The Social Business Initiative of the European Commission. https:// ec.europa.eu/docsroom/documents/14583/attachments/3/translations/en/renditions/pdf

European Movement in Serbia. (2011). Capacity building of local institutions for the development of alternative economy potential in Serbia. http://arhiva.emins.org/uploads/useruploads/projektipdf/Prirucnik_za_treninge_rsp.pdf

Fici, A. (2015). Recognition and Legal Forms of Social Enterprise in Europe: A Critical Analysis from Comparative Law Perspective. Euricse Working Papers, 82/15. https://www.euricse.eu/wp-content/uploads/2015/12/WP-82_15_Fici2.pdf

General Rules of Cooperative Union of Yugoslavia, (1998). Official Gazette of SRJ, Nos. 25/98.

Hofstede, G. (2001). Culture's Consequences: Comparing Values, Behaviors, Institutions and Organizations across Nations, Thousand Oaks CA: SAGE Publications.

Labour Law. (2005). Official Gazette of RS, Nos. 24/2005, 61/2005, 54/2009, 32/2013, 75/2014, 13/2017, 113/2017, 95/2018.

Law on Cooperatives. (1989). Official Gazette of SRS, Nos. 57/89.

Law on Cooperatives. (1996). Official Gazette of SRJ, Nos. 41/96, 12/98.

Law on Cooperatives. (2015). Official Gazette of RS, Nos. 112/2015.

Law on Endowments and Foundations. (2010). Official Gazette of RS, Nos. 88/2010, 99/2011, 44/2018.

Law on Professional Rehabilitation and Employment of Persons with Disabilities. (2009). Official Gazette of RS, Nos. 36/2009, 32/2013.

Law on Volunteering. (2010). Official Gazette of RS, Nos. 36/2010.

Legal Entity Profit Tax Law. (2001). Official Gazette of RS, Nos. 25/2001, 80/2002, 80/2002, 43/2003, 84/2004, 18/2010, 101/2011, 119/2012, 47/2013, 108/2013, 68/2014, 142/2014, 91/2015, 112/2015, 113/2017, 95/2018.

OECD. (1999). Social Enterprises. Paris: OECD.

Parun Kolin, M., Petrušić, N. (2007). Social enterprises and the role of alternative economy in the processes of European integration, Belgrade: European movement in Serbia. https:// solidarnaekonomija.rs/wp-content/uploads/2018/08/16.-Socijalna-preduzeca-i-uloga-alternativne-ekonomije-u-procesima-evropskih-integracija-2008.pdf

Pavlović, A. (2015). History and development of cooperatives in Serbia, PSS Novi Sad, Current advisor 7. http://5.189.140.16/ svetodavstvo/sites/default/files/ISTORIJAT\%20I\%20RAZVOJ\%20ZADRUGARSTVA\%20\%20U\%20SRBIJI.pdf

Public Procurement Law. (2012). Official Gazette of RS, Nos. 124/2012, 14/2015, 68/2015. 
SeConS. (2013). Comparative analysis of the civil society role in the provision of social protection services in the Balkans, Belgrade: SeConS. https://www.secons.net/files/publications/30-Komparativna $\% 20$ analiza $\% 20$ uloga $\% 20$ civilnog $\% 20$ dru $\%$ C5\%A1tva $\% 20 u \% 20$ pru\%C5\%BEanju\%20usluga\%20socijalne $\% 20$ za\%C5\%A1tite $\% 20$ na $\% 20$ Zapadnom $\%$ 20Balkanu.pdf

Social enterprise. (2019). https://en.wikipedia.org/wiki/Social_enterprise

Social Enterprise. (2019, April 15). https://www.investopedia.com/terms/s/social-enterprise.asp Stojanović, Ž., Gnjatović, D. (2015). Cooperatives in Serbia: 120 years of the Cooperative Union of Serbia, Belgrade: HESPERIAedu.

The Social Welfare Act. (2011). Official Gazette of RS, Nos. 24/2011.

Third National Report on Social Inclusion and Poverty Reduction in the Republic of Serbia. (2018). http://socijalnoukljucivanje.gov.rs/wp-content/uploads/2018/11/Treci-nacionalni-izvestaj-o-socijalnom-ukljucivanju-i-smanjenju-siromastva-nacrt.pdf

Value Added Tax Law. (2004). Official Gazette of RS, Nos. 84/2004, 86/2004, 61/2005, 61/2007, 93/2012, 108/2013, 6/2014, 68/2014, 142/2014, 5/2015, 83/2015, 5/2016, 108/2016, 7/2017, $113 / 2017,13 / 2018,30 / 2018,4 / 2019$.

Velev, G. ed. (2011). Social entrepreneurship: models, comparative practice and legal framework of social entrepreneurship in Serbia, Belgrade: Group 484. http:/grupa484.org.rs/ wp-content/uploads/2015/09/sp-modeli-i-komparativna-praksa.pdf

Vukmirović, et al. (2014). Economic Impact of Social Enterprises in the Republic of Serbia, Belgrade: Statistical Office of the Republic of Serbia. https:/ec.europa.eu/docsroom/documents/15062/attachments/5/translations/en/renditions/native

What Is A Social Enterprise? A Simple Definition \& 3 Examples (2019). The Good Trade. https://www.thegoodtrade.com/features/what-is-a-social-enterprise

Zakić, V., Nikolić, M. (2018). State financial support to cooperatives in Serbia, Business school, 1(2018), 158-174. https://scindeks-clanci.ceon.rs/data/pdf/1451-6551/2018/145165511801158Z.pdf 
